\title{
Studies on the Relationship Between Thyroid Hormones and Catecholamines. Their Effects on the Cardiac Phospho- rylase Activity and the Cardiovascular System
}

\section{Ryohei OIKAWA}

Department of Medicine II, School of Medicine, Iwate Medical University,

Morioka, Japan (Professor Takeshi Kimura)

Since over 100 years ago, it has been assumed that the excessive thyroid hormone potentiates the action of catecholamines. The mechanism of this interrelationship has been studied by many investigators, but the results have been divergent and have not led to any generally accepted explanation.

In the previous experiment, we confirmed that reserpine-treated hyperthyroid patients showed a definite clinical improvement. For example, in palpitation and sweating, while no change was observed in the basal metabolic rate and the uptake of radioactive iodine. Furthermore, no potentiation was found in the effects of catecholamines on the carbohydrate metabolism in the hyperthyroid rat muscle using a hindquarter preparation technique. It was, therefore, considered desirable to study this interrelationship between the catecholamine and thyroid hormone in two parts, firstly the relationship in the metabolic system, secondly the relationship in the cardiovascular system.

This investigation was undertaken to determine the effects of adrenaline on the cardiac phosphorylase activity and the heart rate in the normal and hyperthyroid rats.

\section{Materials and Methods}

Male Wister strain rats weighing 200-250 gm were kept under identical conditions and they received water and food ad libitum. L-thyroxine was administered, intraperitoneally, to rats in a dose of $100 \mu \mathrm{g}$ per day for 6 days.

Reserpine was administered intraperitoneally in a dose of $0.05 \mathrm{mg}$ per day for 4 days prior to the experiment.

Catecholamine contents of the heart, adrenals, kidney, liver and spleen were determined by the method of von Euler.

Rats were anesthetized by the intraperitoneal administration of sodium pentobarbital. In each experiment, following a 60 -second-period of control, $0.1 \mu \mathrm{g}$ of adrenaline was rapidly injected intravenously to the upper arm vein and the heart rate was measured by electrocardiography for 60 seconds. At the end of the experiment, the heart was quickly removed from the rat and frozen immediately. Phosphorylase activity was assayed by the method of Cori-Illingworth. $50 \mu \mathrm{g}$ of phentolamine was administered intravenously to the upper arm vein and $200 \mu \mathrm{g}$ of propranolol was administered in the same manner. 


\section{Results}

1) After 6 days of treatment with L-thyroxine $100 \mu \mathrm{g} / 100 \mathrm{gm}$ of body weight, the rats showed distinct increase in the heart rate and oxygen consumption.

These rats lost some body weight.

2) The catecholamine contents of the heart, adrenals, kidney and spleen in the hyperthyroid rats were slightly lower compared with those in the untreated rats. These differences, however, were not significant. The catecholamine content of the liver was approximately similar.

Reserpine treatment produced a significant decrease in the catecholamine contents of the heart, adrenals, kidney, liver and spleen.

3) The administration of thyroxine caused an increase in the cardiac phosphorylase activity, which was concomitant with an increase in the heart rate.

The cardiac phosphorylase activity in the rats given thyroxine and reserpine was higher than that in the untreated rats and reserpine inhibited the increase in the heart rate caused by thyroxine. The cardiac phophorylase activity in the rats given reserpine alone was slightly higher than that observed in the untreated rats concomitant with decrease in the heart rate.

The results of these experiments support the general concept that there is no mutual interaction between the concentration of endogenous catecholamine and the thyroid hormone.

4) The cardiac phosphorylase activity was considerably less responsive to noradrenaline than to adrenaline.

5) The cardiac phosphorylase activity was increased by the injection of adrenaline in the untreated rats, whereas it was not affected by adrenaline in the animals pretreated with thyroxine.

The increase in the cardiac phosphorylase activity observed when adrenaline was given to the hyperthyroid rats was not greater than the sum of the respective increase induced by thyroxine or adrenaline.

The results showed no definite effect of adrenaline on the cardiac phosphorylase activity when catecholamine was injected into the rats pretreated with thyroxine.

Injection of adrenaline into the reserpine-treated hyperthyroid rats resulted in an increase in the heart rate. However, it caused no significant change in the cardiac phosphorylase activity.

On the other hand, injection of adrenaline into the reserpine-treated rats resulted in an increase in the heart rate associated with increase in the cardiac phosphorylase activity.

6) In the untreated and hyperthyroid rats, propranolol had a decreasing effect on the heart rate, but no effect on the cardiac phosphorylase activity. On the other hand, phentolamine had no effect on either the cardiac phosphorylase activity or the heart rate.

Propranolol administration followed by adrenaline administration inhibited the in- 
crease in the cardiac phosphorylase activity and the heart rate induced by adrenaline, while phentolamine had no effect on both of them.

From these findings, no evidence was obtained that thyroxine stimulates the beta receptor.

It would appear from the present experiments that the cardiovascular and metabolic effects of adrenaline are not potentiated by thyroxine. (see pp. 599 612) 


\title{
甲状腺ホルモンとカテコールアミンの相関に関する研究
}

\author{
（心筋ホスホリラーゼ活性と心搏数を指標として）
}

岩手医科大学内科学第二講座（主任 : 木村 武 教授)

及川量平

(昭和 44 年 1 月 4 日受付)

ラットを用い心筋ホスホリラーゼ活性，心搏数を指標として甲状腺ホルモンとカテコールアミンの関 係を知ろうとした。 サイロキシンおよびアドレナリンの単独投与では心筋ホスホリラーゼ活性の上昇, 心搏数の增加が観察されたが, 両ホルモンの投与ではての効果が認められなかつた。 また内因性カテコ ールアミンの態度とサイロキシンの作用との間にも関係が認められず，甲状腺機能立進状態ラットに おいて receptor の機能が元進しているといら証拠もえられなかつた。

\section{緒言}

甲状腺機能圥進症の症状である頻脈, 発汗, 心送血量增大, 振せん, 酸素消費量增加などがカテコールア ミンを投与したときの症状ときわめて類似するてとは古くから注目を集めての両者の関係は種々の観点から 論議されてきたが,いまだ明確なる解答をえていない.

私も甲状腺機能九進症におけるカテコールアミンの役割に注目し種々の実験を重ねてきた。すすなわち甲状 腺機能立進症患者の夜間框眠時の尿中カテコールアミンおよびその代謝産物を測定したてとろ, 排泄量高值 を示す症例があり，レセルピン投与を行なうと排泄量は著明に減少するとともに頻脈のあつた症例では全て 心搏数の減少を認めたが, 基礎代謝率, ${ }^{131} \mathrm{I}$ 椇取率などには変化を認めなかつた事実 ${ }^{1)}$, ラットの後肢灌流 法を用いた実験でサイロキシンにより元進した筋内内の糖代謝に対しカテコールアミンがなんらの影響もお よぼさなかつた事央”は丑状腺機能九進症におけるカテコールアミンの役割を論ずる上で循環器系の症状と その他の症状を分離して考える必要があると推論しできた。

今回はサイロキシン投与により甲状腺機能進状態となつたラットを用い，心搏数，心筋内ホスホリラー ゼ活性を指標とし，カテコールアミンが甲状腺機能元進症のなりたちの上でいかなる役㓶をはたしているか を中心としてうかがい知ううとし，次のでとき実験を行なつた。

\section{対象および実験方法}

1 ）対象, 雄性ウイスター系アルビノラット体重 200〜250gm を用いた.

L-サイロキシン $100 \mu \mathrm{g}$. を0.01規定苛性ソーダ $0.2 \mathrm{cc}$ に含まれるように溶解し, 每日連続 6 日間腹腔内に 投与し甲状腺機能儿進状態のラットを作成し実験に供した。

レセルピンは $0.05 \mathrm{mg}$ を実験前 4 日間腹腔内に投与した。なお麻酔はペントバルビタールソーダ $5 \mathrm{mg} / 100$ $\mathrm{mg}$ を腹腔内に投与して行なつた。

\section{2 ) 組織内カテコールアミン測定法}

Euler の方法に準じて測定を行なつた ${ }^{32}$.

ペントバルビタール麻酔下に藏器を摘出, 直ちに凍結し, 心, 腎, 肺および脾においてはその $0.4 \sim 0.5 \mathrm{mg}$ に 10 倍量の 0.4 規定過塩素酸を加え, 副腎においてはその両側を坪量し同様に過塩素酸を加え Potter-Elvehjem のホモジェナイザーを用いてホモジェナイズを行ない，邆心後上清を苛性ソーダにて pH8.3 亿合 
せ0.2 gm の酸化アルミナにバッチ法にて吸着させ， 0.35 規定酢酸にて抽出した．抽出液に $\mathrm{pH} 6.22$ の 1 規 定酢酸緩衝渡を加えたのち0.25\%フェリシアンカリ化を加えて螢光を発せしめ, 日立螢光光度計 EPL 2 型 にて虽光測定を行なつた。

\section{3) ホスホリラーゼ活性測定法}

Gori-Illingworth の方法に準じて測定を行なつた。すなわち $0.5 \mathrm{gm}$ 前後の組織に20倍量の0.02 ル，フ ッ化ソーダ溶液 $(\mathrm{pH} 6.8)$ 打よび0.001モル，エチレンジアミン 4 酢酸塩溶液 (pH6.8) を加え $4{ }^{\circ} \mathrm{C} の$ 水室内 で Potter-Elvehjem のホモジェナイザーにてホモジェナイズする，ての酵素稀釈液を 2 本の試験管にとり $4 \%$ リコーゲン溶液を加え $30^{\circ} \mathrm{C}$ と20分間 incubation しさらに一方に 0.064 モル，グルコースー 1 一燐 酸ナトリウム溶液（pH6.8）を加え，一方には 0.064 モル，グルコースー1 一燐酸ナトリウム溶液 $(\mathrm{pH} 6.8)$ に0.004 モルなるように5'アデノシンモノホスフェートの入つた溶液を加え，5分後硫酸にて酕素反応 を停止せしめ，生成した無機リン酸を Fiske-Subbalow の方法で定量をした.

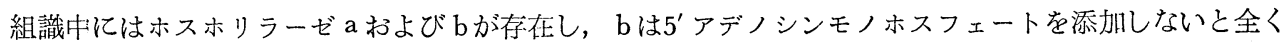
活性を現わさず， a は5 $5^{\prime}$ アデノシンモノホスフェートが共存しなくとも活性であるといわれている．私は全 ホスホリラーゼ值に対する $\mathrm{a}$ ホスホリラーゼ值の割合をもつてホスホリラーゼ活性を表現した.

\section{4) ラット心搏数測定法}

ペントバルビタールソーダにて麻酔をかけたラットを板上に背位に固定，常用の心電計の誘導子の尖端に 注射針を固定，心搏数測定時に皮下に針をさし，記録紙上に描写された心搏数をかぞえて 1 分間あたりの心 搏数を算定した.

\section{5 ）組織内グリコーゲン測定法 ${ }^{5)}$}

沸騰せる30\%苛性カリ溶液中に組識を投じ液化したならば $96 \%$ アルコールを加え沸騰せしもたのち遠心し 上清をすてる.さらにアルコールを加え, 沸騰, 遠心の操作をくりかえしたのち, 管壁に沈澱, 附着したグ リコーゲンを水にて溶解，硫酸にて加水分解を行なつてから中和しその一定量につき Hagedorn-Jensen の方法にて測定，糖量として表した。

\section{結 果}

1）サイロキシン投与によりラットが甲状腺機能立進状態となつたかいなかを知るために次のでとき奏験 を行なつた。

すなわちラットを容量 $3,500 \mathrm{cc}$ の密閉した容器内に30分間静置しその前後の, 容器内の然気の酸素含有量 を学研式ガス分析計にて測定し，その差から 1 分間あたりの酸素消費量を算定した.

表(1)に示すごとく無処置ラットの平均体重は $247 \mathrm{gm} ， 1$ 分間あたりの平均酸素消費量は $0.93 \mathrm{cc} / \mathrm{min}$ ，サ イロキシン $100 \mu \mathrm{g}$ 連日 6 日間腹腔内投与後の平均体重は $220 \mathrm{gm}$, 平均酸素消費量は $1.95 \mathrm{cc} / \mathrm{min}$ でありサ イロキシン投与後に体重減少と酸素消費量の増加を認めた。このととからサイロキシン投与によりラットが 甲状腺機能亢進状態になつたと考え以後の実験では甲状腺機能元進状態ラットの作製には Lーサイロキシン $100 \mu \mathrm{g}$ を連日 6 日間投与して実験に供した。なおサイロキシン投与後の経日的な酸素消費量の増加は図(1)に 示すでとく, 投与 3 日目より著しく増加した值を示し 6 日目にて投与前值の 2 倍に達した.

Table 1. The effect of thyroxine on oxygen consumption

\begin{tabular}{c|c|c|c|c|c|c}
\hline \multirow{2}{*}{$\begin{array}{c}\text { No. of } \\
\text { Animals }\end{array}$} & \multicolumn{2}{|c|}{ Control } & \multicolumn{4}{c}{ Thyroxine ${ }^{\text {a) }}$} \\
\cline { 2 - 7 } & Body Weight & $\begin{array}{l}\mathrm{O}_{2} \text { Consump- } \\
\text { tion/min }\end{array}$ & Body Weight & $\mathrm{P}$ & $\begin{array}{l}\mathrm{O}_{2} \text { Consump- } \\
\text { tion/min }\end{array}$ & $\mathrm{P}$ \\
\hline 7 & $247 \pm 19$ & $0.93 \pm 0.32$ & $220 \pm 18$ & $<0.001$ & $1.95 \pm 0.43$ & $<0.005$ \\
\hline
\end{tabular}

a) $100 \mu \mathrm{g} /$ day i.p. for 6 days. 
2 ）ラットの組織内カテコールアミン含有量にお よぼすサイロキシンの影響.

無処置ラットおよびサイロキシン投与ラットをペ ントバルビタールにて麻酔後断頭殺害し副腎, 心,

腎，肝，脾を摘出し，ただちに凍結，凍結後重量を 測定の上組織内カテコールアミン含有量を測定した。 なお心については左室内のカテコールアミン量を測 定した。

その結果は表(2)に示すごとく用状腺機能元進状態 ラットにおいて肺を除いた副腎，心，掔，脾各臓器 内のカテコールアミン含有量は無処置群に比しやや 低值を示したが有意の差は認められなかつた。

3 ）ラット組識内カテコールアミン含有量におよ ぼすレセルピンの影響.

組織内カテコールアミンの releaser といわれる レセルピンを $0.05 \mathrm{mg}$ あて 4 日間腹腔内に投与した のち前項のごとくペントバルビタール麻酔下にラッ トを断頭殺害し副腎，心，腎，肝、脾内のカテコー ルアミン含有量を測定すると表(3)に示すごとくレセ ルピン投与群では無姏置群にくらべ全藏器に抽て カテコールアミン含有量は有意の減少した值を示した。

4 ）心筋ホスホリラーゼ活性に抢よぼすサイロキシンおよびレセルピンの影響.

無処置群，サイロキシン投与群，サイロキシン十レセルピン投与群，レセルピン投与群各々の心笳ホスホリ ラーゼ活性 (左室) を測定すると，表(4)に示すどとく無処置群では $33.3 \pm 11.3 \% ，$ サロキシン投与群では $44.5 \pm 8.6 \%$ と有意の上昇を䜑め，サイロキシン投与により心筋内糖代謝が无進したてとを示している。サ イロキシン十レセルピン投与群ではサイロキシン投与群よりも心筋ホスホリラーゼ活性は $56.3 \pm 16.9 \%$ とさ らに高值を示した。レセルピン投与群では $37.5 \pm 12.9 \%$ 無処置群と有意の差を認めなかつた。

5 ) 肝ホスホリラーゼ活性におよぼすサイロキシンおよびレセルピンの影響.

無処置群，サイロキシン投与群，サイロキシン+レセルピン投与群，レセルピン投与群の各々の肝ホスホ

Table 2. The effect of thyroxine on the catecholamine concentration in the various organ of rat

\begin{tabular}{|c|c|c|c|c|c|}
\hline \multirow[b]{2}{*}{ Organ } & \multicolumn{2}{|r|}{ Control Rats } & \multicolumn{2}{|c|}{ Hyperthyroid Rats ${ }^{a}$} & \multirow[b]{2}{*}{$\mathrm{P}$} \\
\hline & $\mid \begin{array}{c}\text { No. of } \\
\text { Animals }\end{array}$ & $\begin{array}{c}\text { Catecholamine } \\
\text { Concentration }\end{array}$ & $\left|\begin{array}{c}\text { No. of } \\
\text { Animals }\end{array}\right|$ & $\begin{array}{c}\text { Catecholamine } \\
\text { Concentration }\end{array}$ & \\
\hline $\begin{array}{l}\text { Adrenal } \\
\text { Gland }\end{array}$ & 10 & $\begin{array}{c}\text { Adrenaline } \\
42.84 \pm 10.14 \mu \mathrm{g} / \text { pair }\end{array}$ & 10 & $\begin{array}{c}\text { Adrenaline } \\
35.85 \pm 8.86 \mu \mathrm{g} / \text { pair }\end{array}$ & $>0.1$ \\
\hline Heart & 10 & $\begin{array}{l}\text { Noradrenaline } \\
1.04 \pm 0.47 \mu \mathrm{g} / \mathrm{g}\end{array}$ & 10 & $\begin{array}{l}\text { Noradrenaline } \\
0.83 \pm 0.32 \mu \mathrm{g} / \mathrm{g}\end{array}$ & $>0.1$ \\
\hline Kidney & 10 & $\begin{array}{l}\text { Noradrenaline } \\
0.75 \pm 0.33 \mu \mathrm{g} / \mathrm{g}\end{array}$ & 10 & $\begin{array}{l}\text { Noradrenaline } \\
0.67 \pm 0.16 \mu \mathrm{g} / \mathrm{g}\end{array}$ & $>0.05$ \\
\hline Liver & 10 & $\begin{array}{l}\text { Noradrenaline } \\
0.33 \pm 0.15 \mu \mathrm{g} / \mathrm{g}\end{array}$ & 10 & $\begin{array}{l}\text { Noradrenaline } \\
0.35 \pm 0.19 \mu \mathrm{g} / \mathrm{g}\end{array}$ & $>0.6$ \\
\hline Spleen & 10 & $\begin{array}{l}\text { Noradrenaline } \\
0.61 \pm 0.31 \mu \mathrm{g} / \mathrm{g}\end{array}$ & 10 & $\begin{array}{l}\text { Noradrenaline } \\
0.56 \pm 0.12 \mu \mathrm{g} / \mathrm{g}\end{array}$ & $>0.05$ \\
\hline
\end{tabular}

a) $100 \mu \mathrm{g} /$ day i.p. for 6 days. 
Table 3. The effect of reesrpine on the catecholamine concentration in the various organ of rat

\begin{tabular}{|c|c|c|c|c|c|}
\hline \multirow{2}{*}{ Organ } & \multicolumn{2}{|r|}{ Control Rats . } & \multicolumn{2}{|c|}{ Reserpinized Rats $\left.{ }^{a}\right)$} & \multirow[b]{2}{*}{$\mathbf{P}$} \\
\hline & $\mid \begin{array}{c}\text { No. of } \\
\text { Animals }\end{array}$ & $\begin{array}{r}\text { Catecholamine } \\
\text { Concentration }\end{array}$ & $\left|\begin{array}{c}\text { No. of } \\
\text { Animals }\end{array}\right|$ & $\begin{array}{c}\text { Catecholamine } \\
\text { Concentration }\end{array}$ & \\
\hline $\begin{array}{l}\text { Adrenal } \\
\text { Gland }\end{array}$ & 10 & $\begin{array}{c}\text { Adrenaline } \\
42.84 \pm 10.14 \mu \mathrm{g} / \text { pair }\end{array}$ & 6 & $\begin{array}{c}\text { Adrenaline } \\
27.62 \pm 8.10 \mu \mathrm{g} / \text { pair }\end{array}$ & $<0.01$ \\
\hline Heart & 10 & $\begin{array}{l}\text { Noradrenaline } \\
1.04 \pm 0.47 \mu \mathrm{g} / \mathrm{g}\end{array}$ & 6 & $\begin{array}{l}\text { Noradrenaline } \\
0.16 \pm 0.05 \mu \mathrm{g} / \mathrm{g}\end{array}$ & $<0.05$ \\
\hline Kidney & 10 & $\begin{array}{l}\text { Noradrenaline } \\
0.75 \pm 0.33 \mu \mathrm{g} / \mathrm{g}\end{array}$ & 6 & $\begin{array}{l}\text { Noradrenaline } \\
0.11 \pm 0.04 \mu \mathrm{g} / \mathrm{g}\end{array}$ & $<0.05$ \\
\hline Liver & 10 & $\begin{array}{l}\text { Noradrenaline } \\
0.33 \pm 0.15 \mu \mathrm{g} / \mathrm{g}\end{array}$ & 6 & $\begin{array}{l}\text { Noradrenaline } \\
0.07 \pm 0.02 \mu \mathrm{g} / \mathrm{g}\end{array}$ & $<0.05$ \\
\hline Spleen & 10 & $\begin{array}{c}\text { Noradrenaline } \\
0.61 \pm 0.31 \mu \mathrm{g} / \mathrm{g}\end{array}$ & 6 & $\begin{array}{l}\text { Noradrenaline } \\
0.29 \pm 0.09 \mu \mathrm{g} / \mathrm{g}\end{array}$ & $<0.05$ \\
\hline
\end{tabular}

a) $0.05 \mathrm{mg} /$ day i.p. for 4 days.

Table 4. The influence of reserpine on the action of thyroxine on cardiac phosphorylase activity

\begin{tabular}{|c|c|c|c|}
\hline Pretreatment of Animals & No. of Animals & Phosphorylase a $\%$ of total \pm S.E.M. & $\mathbf{P}$ \\
\hline Control & 10 & $33.3 \pm 11.3$ & $x$ \\
\hline Thyroxine $^{a}$ ) & 9 & $44.5 \pm 8.6$ & $<0.05$ \\
\hline $\begin{array}{c}\text { Thyroxine }^{\mathrm{a})} \\
+ \\
\text { Reserpine }^{\mathrm{b})}\end{array}$ & 6 & $56.3 \pm 16.9$ & $<0.05$ \\
\hline Reserpine $\left.^{b}\right)$ & 6 & $37.5 \pm 12.9$ & $>0.5$ \\
\hline
\end{tabular}

a) $100 \mu \mathrm{g} /$ day i.p. for 6 days.

b) $0.05 \mathrm{mg} /$ day i.p. for 4 days.

Table 5. The influence of reserpine on the action of thyroxine on hepatic phosphorylase activity

\begin{tabular}{|c|c|c|c|}
\hline Pretreatment of Animals & No. of Animals & Phosphorylase a $\%$ of total \pm S.E.M. & $\mathbf{P}$ \\
\hline Control & 10 & $52.3 \pm 10.8$ & C \\
\hline Thyroxine $^{\text {a) }}$ & 10 & $78.5 \pm 18.6$ & $<0.001$ \\
\hline $\begin{array}{c}\text { Thyroxine }^{\mathrm{a})} \\
+ \\
\text { Reserpine }^{\mathrm{b})}\end{array}$ & 5 & $84.3 \pm 16.8$ & $<0.001$ \\
\hline Reserpine $^{b}$ ) & 6 & $51.3 \pm 12.6$ & $>0.1$ \\
\hline
\end{tabular}

a, b) Drug used in the dosage indicated in Table 4

リラーゼ活性を測定すると, 表(5)に示すでとく無㚮置群では $52.3 \pm 10.8 \%$ と筋ホスホラリーゼ活性より高 い活性を示した。 サイロキシン投与群では78.5 $18.6 \%$ 無処置群に比し有意の上昇を認めた。

サイロキシン十レセルピン投与群では心筋ホスホリラーゼ活性と同様に $84.3 \pm 16.8 \%$ 華イロキシン投与 群よりさらに高值を示した。レセルピン投与群ではホスホリラーゼ活性は $51.3 \pm 12.6 \%$ と無処犆と差異がな かつた.

6) 大腿筋のホスホリラーゼ活性におよぼすサイロキシンおよびレセルピンの影響.

無処置群，サイロキシン投与群，サイロキシン+レセルピン投与群，レセルピン投与群各々の大腿筋ホス ホリラーゼ活性を測定すると表(6)に示すでとく無処置群では $25.3 \pm 6.8 \%$ 心筋ホスホリラーゼ活性より低 
Table 6. The influence of reserpine on the action of thyroxine on phosphorylase activity of femoral muscle

\begin{tabular}{c|c|c|c}
\hline Pretreatment of Animals & No. of Animals & Phosphorylase a\% of total \pm S.E.M. & P \\
\hline Control & 10 & $25.3 \pm 6.8$ & $>0.05$ \\
\hline $\begin{array}{c}\text { Thyroxine }^{\mathrm{a})} \\
\begin{array}{c}\text { Thyroxine }^{\mathrm{a}} \text { ) } \\
\text { Reserpine }^{\mathrm{b})}\end{array}\end{array}$ & 10 & $43.4 \pm 20.2$ & $<0.05$ \\
\hline \begin{tabular}{c} 
Reserpine $^{\mathrm{b})}$ \\
\hline
\end{tabular} & 6 & $46.3 \pm 15.8$ & $>0.7$ \\
\hline
\end{tabular}

a, b) Drug used in the dosage indicated in Table 4

Table 7. The effect of thyroxine on the glycogen content in the various organ of rat

\begin{tabular}{c|c|c|c|c}
\hline \multirow{2}{*}{ Organ } & No. of Animals & \multicolumn{2}{|c|}{ Glycogen Content mg/g w.w } & P \\
\cline { 3 - 5 } & & Control Rats & Hyperthyroid Rats & \\
\hline Heart & 10 & $4.14 \pm 1.18$ & $1.59 \pm 0.84$ & $<0.001$ \\
Muscle & 10 & $2.93 \pm 1.35$ & $2.28 \pm 0.60$ & $>0.05$ \\
Liver & 10 & $19.80 \pm 4.83$ & $6.82 \pm 2.12$ & $<0.05$ \\
\hline
\end{tabular}

a) $100 \mu \mathrm{g} /$ day i.p. for 6 days.

Table 8. The effect of adrenaline on cardiac phosphorylase activity and heart rate

\begin{tabular}{c|c|c|c|c}
\hline \hline Drug injected & No. of Animals & $\begin{array}{c}\text { Phosphorylase a\% } \\
\text { of total S.E.M. }\end{array}$ & $\mathrm{P}$ & $\begin{array}{c}\text { Increment \% of } \\
\text { Heart Rate } \pm \text { S.E.M. }\end{array}$ \\
\hline Control & 10 & $33.3 \pm 11.3$ & & \\
Adrenaline $0.03 \mu \mathrm{g}$ & 3 & $32.6 \pm 9.4$ & $>0.8$ & $1.1 \pm 1.9$ \\
$0.06 \mu \mathrm{g}$ & 3 & $54.6 \pm 10.0$ & $<0.001$ & $6.8 \pm 1.1$ \\
$0.10 \mu \mathrm{g}$ & 3 & $58.3 \pm 25.8$ & $<0.005$ & $9.9 \pm 4.4$ \\
$0.15 \mu \mathrm{g}$ & 3 & $50.4 \pm 12.9$ & $<0.01$ & $1.0 \pm 1.4$ \\
$0.20 \mu \mathrm{g}$ & 3 & $68.1 \pm 21.5$ & $<0.001$ & 0 \\
$0.30 \mu \mathrm{g}$ & 3 & $52.6 \pm 7.8$ & $<0.005$ & $5.2 \pm 4.2$ \\
\hline
\end{tabular}

值を示した。 サイロキシン掞与群では $43.4 \pm 20.2 \%$ 無処置群にくらべ有意の上昇を示した. サイロキシ十 ンレセルピン投与群では，心筋に扑いてみられと同様にサイロキシン投与群よりも $46.3 \pm 15.8 \%$ 高值を 示した.レセルピン投与群の大腿笳ホスホリラーゼ活性は $27.2 \pm 13.9 \%$ 無置群と差異を認ぬなかつた。

7 ）ラットの組織内グリコーゲン含有量におよぼすサイロキシンの影響.

前項に示したでとくサイロキシン投与により心, 大腿筋, 肝ホスホリラーゼ活性は上昇した值を示し, 糖 代謝の亢進をきたしているととをうかがい知ることが出来たが，糖代謝尣進の結果として当然組織内のグリ コーゲン含有量は低下しているととと考えられる.

心筋，大腿筋，肝内グリコーゲン含有量を測定すると表(7)に示すでとく心筋および肝ではサイロキシン投与 後に有意の減少した值を示した。しかし大腿筋ではサイロキシン投与後にグリコーゲン含有量は減少した值 を示したが有意の差はなかつた。

$8 ）$ 心筋ホスホリラーゼ活忙および心博数におよぼすアドレナリンの是的関係

ラットをペントバルビタール麻酔下に背位に固定，上腕静脈を露出したのち心搏数测定のために心電計の誘 
導子を装着して, 1 分間心搏数を測定したのち, 生理的食塩水 $0.1 \mathrm{cc}$ 亿塩酸 L-アドレナリンが $0.03,0.06$, $010,0.15,0.20,0.30 \mu \mathrm{g}$ 含まれるように溶解し, 上腕静脈上り注入, 注入後 1 分間の心搏数を测定して注入 前の心博数と比較し, 増加の割合をパーセンテージにて示した. 又アドレナリン注入を行ない 1 分間心搏数 を測定したのち，ただちに心を摘出し凍結の上ホスホリラーゼ活性を測定した。

表(8)に示すでとくアドレナリン量 $0.03 \mu \mathrm{g}$ ではホスホリラーゼ活性, 心搏数とも增加した值を示さなかつ たが，0.06 $\mu \mathrm{g}$ では両者とも増加した值を示し， $0.10 \mu \mathrm{g}$ ではさらに増加した值を示した．

心搏数の增加は $0.10 \mu \mathrm{g}$ 以上の投与では認利られななつたが，一方ホスホリラーゼ活性は $0.15 \mu \mathrm{g}$ でや や低下した值を示し， $0.20 \mu \mathrm{g}$ では対象群の 2 倍の值を示した。しかしアドレナリン $0.30 \mu \mathrm{g}$ ではホスホリラ 一ゼ活性はむしろ低下した值を示した。

この結果から私はアドレナリンの注入量を心搏数，ホスホリラーゼ活性ともに上:昇した值を示した $0.10 \mu \mathrm{g}$ と定め, 以後全てての量を用いて実験を行なつた。

9) 心筋ホスホリラーゼ活性および心搏数におよぼすノルアドレナリンの量的関係.

前項に示したでとき処置を行なつたラットを用いノルアドレナリンの心筋ホスホリラーゼ活性および心搏

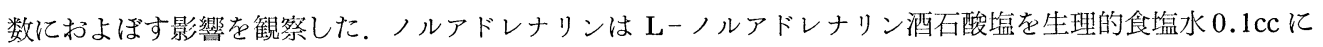
$0.1,0.2,0.4,0.8 \mu \mathrm{g}$ 合まれるように浴解して上腕静脈より注入して実駼を行なつた。

ノルアドレナリン注入後の心筋ホスホリラーゼ活性の上昇は表(9)飞示すでとくアドレナリン注入時とくら べ著しく低かつた。一方心搏数の増加はノルアドレナリン $0.2 \mu \mathrm{g}$ 投与で $7.5 \%$ 増加, $0.4 \mu \mathrm{g}$ で $3.8 \%, 0.8 \mu \mathrm{g}$ にて $6.9 \%$ 増加を認めた。 なお生理的食塩水のみの投与では心筋ホスホリラーゼ活性, 心搏数にはななら の変化も認めなかつた，てのようにノルアドレナリンの心筋ホスホリラーゼ活性におよぼす影響はアドレナ リンにくらべて少く，今回の実験ではアドレナリンを用いて実験を行なうとととした。

10）サイロキシン投与およびレセルピン投与ラットの心筋ホスホリラーゼ活性におよぼすアドレナリンの 影響.

Table 9. The effect of noradrenaline on cardiac phosphorylase activity and heart rate

\begin{tabular}{c|c|c|c|c}
\hline Drug injected & No. of Animals & $\begin{array}{c}\text { Phosphorylase a } \\
\text { of total S.E.M. }\end{array}$ & P & $\begin{array}{c}\text { Increment \% of } \\
\text { Heart Rate } \pm \text { S.E.M. }\end{array}$ \\
\hline Control & 10 & $33.3 \pm 11.3$ & & \\
Noradrenaline 0.1 $\mu \mathrm{g}$ & 3 & $36.6 \pm 7.6$ & $>0.4$ & $1.2 \pm 1.4$ \\
$0.2 \mu \mathrm{g}$ & 3 & $35.1 \pm 1.6$ & $>0.05$ & $7.5 \pm 0.2$ \\
$0.4 \mu \mathrm{g}$ & 3 & $39.1 \pm 13.6$ & $>0.2$ & $3.8 \pm 3.1$ \\
$0.8 \mu \mathrm{g}$ & 3 & $41.9 \pm 2.7$ & $>0.05$ & $6.9 \pm 4.5$ \\
\hline
\end{tabular}

Table 10. The effect of adrenaline on the cardiac phosphorylase activity in the hyperthyroid rats and reserpinized rats

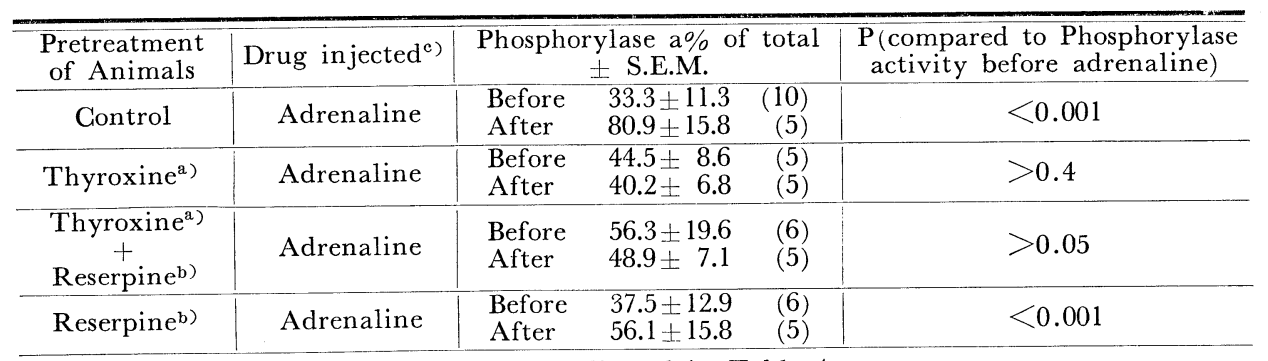

a, b) Drug used in the dosage indicated in Table 4

c) $0.1 \mu \mathrm{g}$ i.v.

( ) : Number of animals. 
Table 11. The influence of reserpine on the action of thyroxine on heart rate

\begin{tabular}{|c|c|c|c|}
\hline Pretreatment of Animals & No. of Animals & Heart Rate per minute \pm S.E.M. & $\mathrm{P}$ \\
\hline Gontrol & 5 & $326 \pm 47$ & 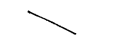 \\
\hline Thyroxine $^{\mathrm{a})}$ & 4 & $437 \pm 26$ & $<0.001$ \\
\hline $\begin{array}{c}\text { Thyroxine }^{\mathrm{a})} \\
+ \\
\text { Reserpine }^{\mathrm{b})}\end{array}$ & 5 & $308 \pm 52$ & $>0.6$ \\
\hline Reserpine $\left.^{b}\right)$ & 5 & $238 \pm 12$ & $<0.05$ \\
\hline
\end{tabular}

a, b) Drug used in the dosage indicated in Table 4

Table 12. The effect of adrenaline on the heart rate in the hyperthyroid rats and reserpinized rats

\begin{tabular}{|c|c|c|c|c|c|}
\hline $\begin{array}{l}\text { Pretreatment } \\
\text { of Animals }\end{array}$ & Drug injected $\left.{ }^{\mathrm{c}}\right)$ & \multicolumn{3}{|c|}{$\begin{array}{l}\text { Heart rate per } \\
\text { minute } \pm \text { S.E.M. }\end{array}$} & $\begin{array}{r}\text { P (compared to heart rate } \\
\text { before adrenaline) }\end{array}$ \\
\hline Control & Adrenaline & $\begin{array}{l}\text { Before } \\
\text { After }\end{array}$ & $\begin{array}{l}326 \pm 47 \\
336 \pm 21\end{array}$ & $\begin{array}{l}(5) \\
(5)\end{array}$ & $>0.7$ \\
\hline Thyroxine $^{\mathrm{a})}$ & Adrenaline & $\begin{array}{l}\text { Before } \\
\text { After }\end{array}$ & $\begin{array}{l}437 \pm 26 \\
448 \pm 31\end{array}$ & $\begin{array}{l}(5) \\
(5)\end{array}$ & $>0.6$ \\
\hline $\begin{array}{c}\text { Thyroxine }^{\mathrm{a})} \\
+ \\
\text { Reserpine }^{\mathrm{b})}\end{array}$ & Adrenaline & $\begin{array}{l}\text { Before } \\
\text { After }\end{array}$ & $\begin{array}{l}308 \pm 52 \\
372 \pm 46\end{array}$ & $\begin{array}{l}5 \\
(5) \\
(5)\end{array}$ & $>0.05$ \\
\hline Reserpine $\left.^{b}\right)$ & Adrenaline & $\begin{array}{l}\text { Before } \\
\text { After }\end{array}$ & $\begin{array}{l}238 \pm 12 \\
284 \pm 6\end{array}$ & $\begin{array}{l}(5) \\
(5)\end{array}$ & $<0.001$ \\
\hline
\end{tabular}

a, b) Drug used in the dosage indicated in Table 4

c) $0.1 \mu \mathrm{g}$ i.v.

( ) : Number of animals.

無処置群，サイロキシン投与群，サイロキシントレセルピン投与群，レセルピン投与群各々にペントバル ビタール麻酔下にてアアドレリン $0.1 \mu \mathrm{g}$ を生理的食塩水 $0.1 \mathrm{cc}$ に溶解し，上腕静脈より注入し， 1 分後心を摘 出し心筋ホスホリラーゼ活性を測定しアドレナリンの心脇ホスホリラーゼ活性におよぼす影響をみると表(10) に示すでとく無処置群においてアドレナリン投与前の心筋ホスホリラーゼ活性は $33.3 \pm 11.3 \%$ あっつたがア ドレナリン投与により心筋ホスホリラーゼ活性は $80.9 \pm 15.8 \%$ と有意の上昇を認めた。 しかしサイロキシン およびサイロキンシ十レセルピン投与群ではアドレナリン投与によつて心筋ホスホリラーゼ活性は上昇しな かつた。レセルピン投与群では心筋ホスホリラーゼ活性はアドレトリン投与により $56.1 \pm 15.8 \%$ 有意の差 を示しそ。しかしその上昇の度合は無処置群より少かつた。

11）無処置およびサイロキシン投与ラットの心搏数に抢よぼすレセルピンの影響.

表(11)に示すごとく無処置ラットの心搏数は $326 \pm 47 / \mathrm{min}$ ，サイロキシン投与を行ない甲状腺機能六進状態 となつたラットの心搏数は $437 \pm 26 / \mathrm{min}$ を有意に増加した值を示したがサイロキシン投与と共にレセルピ ン投与を行なうとサイロキシンによる心搏数の増加は抑制され $308 \pm 52 / \mathrm{min}$ とむしろ無処置ラットの心搏 数より低い伹を示した。一方レセルピン投与群では心搏数は $238 \pm 12 / \mathrm{min}$ で無処置群に比し有意の減少を 示した.

12）サイロキシン投与およびレセルピン投与ラットの心搏数におよぼすアドレナリンの影響.

表(12)亿示すざとく無処置群，サイロキシン投与群，サイロキシン十レセルピン投与群，レセルピン投与群 各々にペントバルビタール麻酔下に上腕静脈よりアドレナリン $0.1 \mu \mathrm{g}$ を生理的食塩水 $0.1 \mathrm{cc}$ 亿溶解し投与す るとレセルピン投与群においてのみ心搏数はアドレナリン投与により有意の増加を認めたが，他の 3 群では 有意の変化を示さなかつた。

13）フェントラミン，プロプラノロールの然処置ラット心觔ホスホリラーゼ活性におよぼす影響.

$\alpha$-Blockade であるフェントラミン, $\beta$-Blockade であるプロプラノロールの心筋ホスホリラーゼ活性にお 
よぼす影響を観察した。プロプラノロールは，ペントバルビタール麻酔下に上胞静脈より $100 \mu \mathrm{g} / 100 \mathrm{gm}$ を 10 秒間にて注入, 注入 1 分後に心を摘出し心筋ホスホリラーゼ活性を測定した。 プロプラノロール十アドレ ナリン投与は，上述のでとくプロプラノロールを注入し 1 分後，アドレナリン $0.1 \mu \mathrm{g}$ を同様に上腕静脈より 注入し， 1 分後心を摘出し心筋ホスホリラーゼ活性を測定した. フェントラミンは上腕静脈より $25 \mu \mathrm{g} / 100 \mathrm{gm}$ を10秒間にて注入, 注入 1 分後に心を摘出し心筋ホスホりラーゼ活性を測定した。 フェントラミン十アドレ ナリン投与は上述のごとくフェントラミンを注入し， 1 分後にアドレナリン $0.1 \mu \mathrm{g}$ を上腕静脈より注入しさ らに 1 分後心を摘出し心筋ホスホリラーゼ活性を測定した.

表(13)に示すでとくプロプラノロール投与後の心筋ホスホリラーゼ活性は $32.0 \pm 7.0 \%$ 無処置群と変化を 認めず，アドレナリン投与による心筋ホスホリラーゼ活性の上昇はプロプラノロールをあらかじめ投与して おくことにより全く抑制された．乙れに反しフェントラミン投与後の心筋ホスホリラーゼ活性は $37.3 \pm 4.9$ \%と有意の上昇を示すと共に，さらにアドレナリン投与を行なうと心筋ホスホリラーゼ活性は上昇した值を 示し $\beta$-Blockade を投与した場合と異る結果がえられた.

しかし無处置群にアドレナリンのみの投与を行なつた場合の心筋ホスホリラーゼ活性の上昇の度合よりも 少かつた。

Table 13. The influence of propranolol and phentolamine on the action of adrenaline on cardiac phosphorylase activity in the control rats

\begin{tabular}{c|c|c|c|c|c}
\hline Drug injected & Control & Propranolol & $\begin{array}{c}\text { Adrenaline } \\
+ \\
\text { Propranolol }^{\mathrm{b}}\end{array}$ & Phentolamine $^{\mathrm{c})}$ & $\begin{array}{c}\text { Adrenaline } \\
+\mathrm{d}) \\
\text { Phentolamine }^{(}\end{array}$ \\
\hline $\begin{array}{c}\text { Phosphorylase a } \\
\text { of total } \pm \text { S.E.M. }\end{array}$ & $\begin{array}{c}33.3 \pm 11.3 \\
(10)\end{array}$ & $\begin{array}{c}32.0 \pm 7.0 \\
(5)\end{array}$ & $\begin{array}{c}31.0 \pm 4.9 \\
(5)\end{array}$ & $\begin{array}{c}37.3 \pm 2.9 \\
(5)\end{array}$ & $\begin{array}{c}53.5 \pm 14.1 \\
(5)\end{array}$ \\
\hline P & $>0.8$ & $>0.6$ & $<0.05$ & $<0.02$ \\
\hline
\end{tabular}

a) $200 \mu \mathrm{g}$ i.v.

b) $200 \mu \mathrm{g}$ propranolol addition followed in 60 seconds by the addition of $0.1 \mu \mathrm{g}$ adrenaline i.v.

c) $50 \mu \mathrm{g}$ i.v.

d) $50 \mu \mathrm{g}$ phentolamine addition followed in 60 seconds by the addition of $0.1 \mu \mathrm{g}$ adrenaline i. v.

( ) : Number of animals.

Table 14. The influence of propranolol and phentolamine on the action of adrenaline on cardiac phosphorylase activity in the hyperthyroid rats

\begin{tabular}{|c|c|c|c|c|c|}
\hline Drug injected & Thyroxine ${ }^{a}$ ) & $\begin{array}{c}\text { Thyroxine } \\
+ \\
\text { Propranolol }^{\mathrm{b}}\end{array}$ & $\begin{array}{c}\text { Thyroxine } \\
+ \\
\text { Adrenaline } \\
+ \\
\text { Propranolol }\end{array}$ & $\begin{array}{c}\text { Thyroxine } \\
+ \\
\text { Phentolamine }^{\mathrm{d})}\end{array}$ & $\begin{array}{c}\text { Thyroxine } \\
+ \\
\text { Adrenaline } \\
+ \\
\text { Phentolamine }\end{array}$ \\
\hline $\begin{array}{c}\text { Phosphorylase a\% } \\
\text { of total } \pm \text { S.E.M. }\end{array}$ & $\begin{array}{l}44.5 \pm 8.6 \\
(10)\end{array}$ & $\begin{array}{c}43.3 \pm 9.0 \\
(5)\end{array}$ & $\begin{array}{l}42.3 \pm 4.1 \\
(5)\end{array}$ & $\begin{array}{c}52.1 \pm 14.3 \\
(5)\end{array}$ & $\begin{array}{c}47.6 \pm 7.2 \\
(5)\end{array}$ \\
\hline $\mathrm{P}$ & & $>0.9$ & $>0.6$ & $>0.2$ & $>0.5$ \\
\hline
\end{tabular}
a) $100 \mu \mathrm{g} /$ day i.p. for 6 days.
2) $200 \mu \mathrm{g}$ i. v.
c) $200 \mu \mathrm{g}$ propranolol addition followed in 60 seconds by the addition of $0.1 \mu \mathrm{g}$ adrenaline i.v.
d) $50 \mu \mathrm{g}$ i.v.
e) $50 \mu \mathrm{g}$ phentolamine addition followed in 60 seconds by the addition of $0.1 \mu \mathrm{g}$ adrenaline i.v.
( ) : Number of animals. 
Table 15. The influence of propranolol and phentolamine on the action of adrenaline on heart rate in the control rats

\begin{tabular}{c|c|c|c|c|c|c}
\hline Drug injected & Control & Propranolol & $\begin{array}{c}\text { Adrenaline } \\
+ \\
\text { Propranolol }\end{array}$ & Control & Phentolamine $^{\mathrm{c})}$ & $\begin{array}{c}\text { Adrenaline } \\
+ \\
\text { Phentolamine }^{\mathrm{d}}\end{array}$ \\
\hline $\begin{array}{c}\text { Heart Rate per } \\
\text { minute } \pm \text { S.E.M. }\end{array}$ & $\begin{array}{c}346 \pm 32 \\
(5)\end{array}$ & $\begin{array}{c}276 \pm 19 \\
(5)\end{array}$ & $\begin{array}{c}262 \pm 25 \\
(5)\end{array}$ & $\begin{array}{c}322 \pm 48 \\
(5)\end{array}$ & $\begin{array}{c}338 \pm 35 \\
(5)\end{array}$ & $\begin{array}{c}387 \pm 21 \\
(5)\end{array}$ \\
\hline P & $<$ & $<0.005$ & $<0.005$ & $<$ & $<0.6$ & $<0.05$ \\
\hline
\end{tabular}

a) $200 \mu \mathrm{g}$ i.v.

b) $200 \mu \mathrm{g}$ propranolol addition followed in 60 seconds by the addition of $0.1 \mu \mathrm{g}$ adrenaline i.v.

c) $50 \mu \mathrm{g}$ i.v.

d) $50 \mu \mathrm{g}$ phentolamine addition followed in 60 seconds by the addition of $0.1 \mu \mathrm{g}$ adrenaline i.v.

( ) : Number of animals.

Table 16. The influence of propranolol and phentolamine on the action of adrenaline on heart rate in the hyperthyroid rats

\begin{tabular}{|c|c|c|c|c|c|c|}
\hline Drug injected & $\begin{array}{l}\text { Thyro- } \\
\text { xine }^{a}\end{array}$ & $\begin{array}{c}\text { Thyroxine } \\
+ \\
\text { Propranolol }\end{array}$ & $\begin{array}{c}\text { Thyroxine } \\
+ \\
\text { Adrenaline } \\
+ \\
\text { Propranolol } \\
\end{array}$ & Thyroxine & $\begin{array}{c}\text { Thyroxine } \\
+ \\
\text { Phentolamine }^{\mathrm{d})}\end{array}$ & $\begin{array}{c}\text { Thyroxine } \\
+ \\
\text { Adrenaline } \\
+ \\
\text { Phentolamine }\end{array}$ \\
\hline $\begin{array}{l}\text { Heart Rate per } \\
\text { minute } \pm \text { S.E.M }\end{array}$ & $\begin{array}{l}423 \pm 42 \\
(5)\end{array}$ & $\begin{array}{c}351 \pm 27 \\
(5)\end{array}$ & $\begin{array}{l}354 \pm 25 \\
(5)\end{array}$ & $\begin{array}{l}435 \pm 54 \\
(5)\end{array}$ & $\begin{array}{c}456 \pm 49 \\
(5)\end{array}$ & $\begin{array}{l}471 \pm 49 \\
(5)\end{array}$ \\
\hline $\mathrm{P}$ & & $<0.05$ & $<0.05$ & & $>0.5$ & $>0.5$ \\
\hline
\end{tabular}

a) $100 \mu \mathrm{g}$ i.p. for 6 days.

b) $200 \mu \mathrm{g}$ i.p.

c) $200 \mu \mathrm{g}$ propranolol addition followed in 60 seconds by the addition of $0.1 \mu \mathrm{g}$ adrenaline i.v.

d) $50 \mu \mathrm{g}$ i.v.

e) $50 \mu \mathrm{g}$ phentolamine addition followed in 60 seconds by the addition of $0.1 \mu \mathrm{g}$ adrenaline i.v.

( ) : Number of animals.

14）フェントラミン，プロプラノロールのサイロキシン搑与ラットの心筋ホスホリラーゼ活性におよぽす 影響について.

サイロキシン投与により甲状腺機能六進状態となつたラットに前項のごとくプロプラノロール，フェント ラミンおよびアドレナリンを投与した場合の心筋ホスホリラーゼ活性は表(14)に示すでとくプロプラノロール 投与により心筋ホスホリラーゼ活性に变化を認めず，さらにアドレナリンを投与しても心筋ホスホりラーゼ 活性は上昇しなかつた。 またフェントラミン投与では心筋ホスホリラーゼ活性はやや上昇した值を示したが 有意の差ではなかつた。 さらにフェントラミン投与後にアドレナリンを投与しても活性の上昇は認められな かつた.

15）フェントラミン，プロプラノロールの然処置ラットの心搏数に抢よぼす影響について.

無処置ラットをペントバルビタール麻醉下に心電計を装着し前項のごとくプロプラノロール，フェントラ ミンおよびアドレナリンを投与して心搏数の変化を測定すると表(15)に示すどとくプロプラノロール投与によ り心搏数は有意の減少を示した.

プロプラノロール投与後にアドレナリンを投与すると心搏数は減少した值を示したままでアドレナリンの 心搏数に対する効果はプロプラノロールにより抑制された．一方フェントラミン投与のみでは心搏数に著変 を認めなかつたが，プロプラノロールと異りアドレナリンによる心搏数の増加はフェントラミンでは抑制さ れなかつた。 
16）フェントラミン，プロプラノロールのサイロキシン投与ラットの心搏数におよぽす影響について。

サイロキシン投与により甲状腺機能六進状態となつたラットをペントバルビタール林醉下に心電計を装着, 前項のでとくプロプラノロール，フェントラミン抢よびアドレナリンを投与してれら薬剤の心搏数に対する 作用を観察した。

表(16)に示すでとくプロプラノロール投与により甲状腺機能六進状態となつたラットの増加した心搏数は抑 制され無処置ラットの心搏数とほほ同梯の值を示した．またプロプラノロール投与後にアドレナリンを投与 しても心搏数の増加々認められなかつた。一方フェトラミン投与では心搏数に変化を認めず，フェントラミ ン投与後にアドレナリンを投与すると有意の差ではなかつたが心搏数は増加した值を示した。

\section{考按}

甲状腺機能市進症における自律神経系の役割については種々の観点から論議が重ねられてきたが現在の段 階でこの両者の関係に明確なる解答が与えられているとはいはれない.

しかし実験的に甲状腺機能充進症状を呈した犬の症状が交感神経遮断により消失するという Brewster ${ }^{6)} の$ 報告, 頸部交感神経を電気制激し甲状腺静脈血中の蛋白結合ヨード增加を確認した飯野》の報告, 甲状腺機 能六進症患者にレセルピンを投与し心搏数の減少, 振せんおよび眼症状の改善をみたという木村 ${ }^{1)}$, Canary ${ }^{8)}$ の報告, 甲状腺機能穴進症㭧者においては交感神経刺激あるいはカラコールアミン投与のさいの反応性が正 常者より大であるとする Howitt ${ }^{9}$ ， Theilen ${ }^{10)}$ ，Schneckloth ${ }^{11)}$ なぞの報告は甲状腺機能穴進症の成り立ちの上 で自律神経系がなんらかの役割をはたしているととを推祭せしめる。著者は甲状腺亦ルモンと自律神経系の 関係に注目し種々の観点から検討を加えてきたが，今回は甲状腺機能充進状態となつたラットを用い，心筋 ホスホリラーゼおよび心搏数の変化を示標として甲状腺機能充進症におけるカテコールアミンの役割を知ろ うとした。

甲状腺機能六進状態となつた動物をつくりだすためにおおむねの研究者はLーサイロキシンソーダ $100 \mu \mathrm{g} /$ $100 \mathrm{gm}$ 前後を $6 〜 7$ 日間投与して甲状腺機能六進状態となつた動物を作製しているが ${ }^{12}$ (13)14), 著者は L-サ イロキシンソーダ $100 \mu \mathrm{g} / 100 \mathrm{gm}$ をラット腹腔内に連続 6 日間投与し, その前後の酸素消費量, 心搏数およ び体重を湘定し，ラットが甲状腺機能六進状態となつているかいなかを検索した。その結果サイロキシン投 与 6 日後に酸素消費量は 2 倍に, 心搏数は 1.3 倍に増加するとともに体重は減少し，上記の投与量にて立分 甲状腺機能え進状態となつたラットをつくりえたと考㝋実験をすすめた。

ホスホリラーゼは Glycogenolysis の触桇醭素であり，ホスホリラーゼ a およびbが存在し，aはアデノ シンモノホスフェートが存在しなくとも活性であり，bはアデノシンモノホスフェートを添加しなければ全 く不活性であるてとは知られている事実である。

ホスホリラーゼ $\mathrm{a}$ および $\mathrm{b} の$ 值住対するホスホラリーゼ $\mathrm{a}$ の割合をもつてホスホリラーゼ活性を表現する と著者の心筋ホスホリラーゼ活性はラットにおいて実験を行なつた Hornbrook ${ }^{15}$ ，の值より高く，犬において 実験を行なつた Mayer ${ }^{16)}$ ，Wollenberger ${ }^{17)}$ の值より高值であるが，ラットにわいて実験を行なつた Hess ${ }^{18)}$ の值とよく一致する。しかし心を摘出して灌流を行ない心筋ホスホリラーゼ活性を測定すると低值を示し ${ }^{19}$ ),

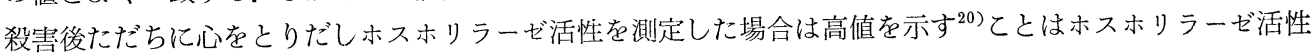
測定の場合にその活性值は実験条件に大きく左右されるととを示しており，実験条件のいかんにより報告の 值に差が生ずるのであろうと考えられる。

レセルピンの甲状腺機能充進症における効果については甲状腺刺激ホルモン分泌を抑刺するという報告 ${ }^{21)}$

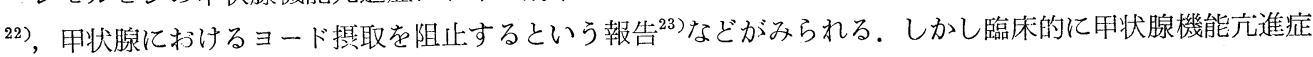
患者にレセルピンを投与すると脈搏数の減少，振せんなどの改善をみるにかかわらず，蛋白結合ヨード，

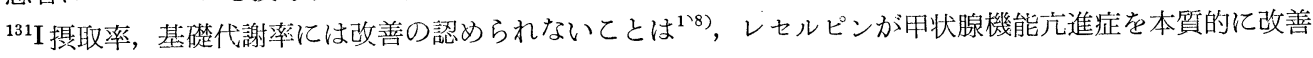
せしめたのではないととを示している。

甲状腺ホルモン投与後の組織内カテコールアミン濃度に関する報告は心筋および副腎に関しての告報がみ 
られるが諸臟器についての報告は数少い24), 由状腺ホルモン投与後の心筋内カテコールアミン濃度に関して は増加するとするもの ${ }^{25)}$, 変化なしとするもの ${ }^{26)}$, 減少するとするもの ${ }^{24)}$ があり副腎内カテコールアミン量

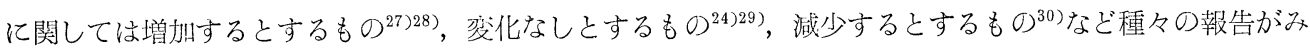

られる。著者の実験においては朋を除いた副腎，心，腎，脾各臓器においてカテコールアミン含有量は やや減少した值を示した。一方甲状腺ホルモン投与後の心筢内ホスホリラーゼ活性についてはホスホリラー

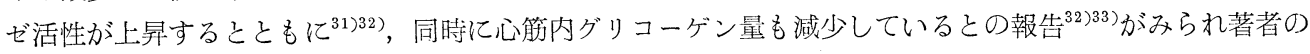
值と一致する。

甲状腺ホルモン投与によりホスホリラーゼ活性の上昇をきたし糖代謝の无進した状態では当然組織内のグ リコーゲン含有量は低下した值を示すものであると考光られる.

組織内カテコールアミン含有量とホスホリラーゼ活性との関係を心, 朋わよび大退筋についてみると，サ イロキシンを投与するととにより組織内カテコールアミン含有量はやや減少した值をとるのにかかわらず， ホスホリラーゼ活性は無処置群より上昇した值を示し，レセルピンを投与するととにより組織内カテコール アミン含有量は著明に減少するにかかわらずホスホリラーゼ活性は無処置群と同様の值を示した，さらに注 目を要するととはサイロキシン投与と同時にレセルピンを投与した群では，サイロキシンを単独で投与した 群よりもホスホリラーゼ活性が上昇するととである。このととはサイロキシンによる組織内のホスホリラー ゼ活性の上昇が組織内カテコールアミン濃度と全くなんらの関係をもたずに行われているととを示している. さらにサイロキシン投与によるホスホリラーゼ活性の上昇がレセルピン投与により組織内カテコールアミン 含有量の減少した状態でさらに強められることが，心，朋，大腿筋各々で観察されたととは興味深い。

レャルピン投与後の心筋内ホスホリラーゼ活性については変化なしとする報告 ${ }^{34)}$, あるいは低下するとい う報告 ${ }^{35}$ が゙られるが，組織内カテコールアミン含有量とホスホリラーゼ活性との間には関係がないとする 報告が多い. 甲状腺機能㠵進症患者にレセルピンを抄与し頻脈その他の臨床症状の改善をるるることは前述 したが，甲状腺機能九進状態となつたラットにレセルピンを投与すると心搏数は無処置群より減少した值を 示したが，無処置ラットにレセルピンを投与しても心搏数は大巾に減少した值を示した。正常人にレセルピ ンを投与しても心搏数の減少は認められないてとを考えると，てのととはラットの心搏数が人の 5 倍以上の 数であるという生理的な相遠にもとづくものと考えられる.

従前よりアドレナリンの metabolic effect はノルアドレナリンより強才であるといわれており Bloom ${ }^{36}$ ， Fleming ${ }^{37)}$ そよればラットにおけるアドレナリンの hyperglycemic effect はノルアドレナリンの 3 倍であり， 同程度の酸素消費量をうけるためにはノルアドレナリンはアドレナリンの5倍の量が必要であるといわれて いる，著者の実験においてもノルアドレナリンにくらベアドレナリンでは心笳ホスホリラーゼ活性におよば す影響が大であつた。

外因性アドレナリンの心筋ホスホリラーゼ活性の上昇については Haugaard ${ }^{38)}, \varnothing_{\text {ye }}{ }^{39}$ ， Mayer ${ }^{16)}$, Drummond $^{40)}$ などの報告がみられ，いずれの報告においてもアドレナリン投与後に心筋ホスホリラーゼ活性の上 昇をみとめている。しかし心筋ホスホリラーゼ活性の上昇と inotropic response との関係については相関 ありとするもの，あるいはなしとするものと種々である.

無処置群, サイロモシン投与群, サイロシシン十レセルルピン投与群, レセルピン投与群各々にアドレナ リンを投与して心筋ホスホリラーゼ活性を測宗すると，アドレナリン投与後の心筋ホスホリラーゼ活性の上 昇は烈好置群において大であり，サイロキシンおよびサイロキシン+レセルビン投与群においてはアドレナ リンを投与しても心筋ホスホリラーゼ活性の上昇が諗められず，サイロキシン投与を行なつたラットにおい てはアドレナリンは心筋ホスホリラーゼ活性になんらの影響も与えないとの結論がえられた。すなわちサイ ロキシンおよびアドレナリンをそれぞれ単独に投与したときには心筋ホスホリラーゼ活性の上昇が認められ るが，サイロキシンおよびアドレナリン両者を投与したときにはアドレナリンの効果がみとめられないので ある.

著者の害験においては心搏数の増加および心筋ホスホリラーゼ活性の上昇をみるアドレナリンの濃度は一 
致しているが, 無处置群, サイロキシン投与群，サイロキシン十レセルピン投与群，レセルピン投与群各々 にアドレナリンを投与して心搏数增加および心筋ホスホリラーゼ活性上昇の関係をみると心筋ホスホリラー ゼ活性の上昇は無処置群，レセルピン投与群においてのみ観察され，アドレナリン投与による心搏数の堌加， 心筋ホスホリラーゼ活性の上昇がサイロキシン投与ラットにおいて無処置ラットより增強された事実は認め られず，サイロキシン投与ラットにおいてはカテコールアミンに対する感受性が高いのではないかという著 者の推測をたしかめうることが出求なかつた。すすなわち状腺機能六進症にわける循環機能の六進は甲状腺 ホルモンとアドレナリンの協働作用によるという Raab ${ }^{41}$ の考觉ううらづけるととは出来なかつた。また無 処置ラットにおいてアドレナリン投与による心搏数が増加10\%程度であるのに反し，サイロキシン投与ラッ トの心搏数は無処置ラットにくらべ30\%以上の増加をみることは組織の代謝六進, 酸素消費量の増加に応じ て循環機能が適応する結果であると考觉られ，サイロキシン投与ラットの心搏增加は adrenergic mechanism を介する機序よりもサイロキシンそのものの心筋に対する作用によるものと考えられる.

1948年 Ahlquist ${ }^{42)}$ は交感神経の支配する器官の反応を二つに分類すると, アドレナリンの作用の二面性が 説明されるととを見出し， $\alpha$ と $\beta$ という二つの異つた受容器を想定した。

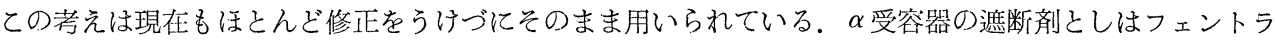
ミンが古くから知られていたが $\beta$ 受容器の遮断剂は長らく見出されなかつた。1958年にいたりダイクロール イソプロテレノール (DCI) が特異的に $\beta$ 作用のみを遮断するととが Powell ${ }^{43}$ により報告された.

その後プロネサロール ${ }^{44)}$ の発見をへてプロプラノロール ${ }^{45}$ が見出され $\beta$ 遮断剤はその地位を確定した。 カ テコールアミンにより Glycogenolysis が増強するため血糖や乳酸が増加し肝のグリコーゲン含有量が減少 するととは知られている事実であるが，ての現象の中間段階飞関して $\alpha$ および $\beta$ 作用といら観点からみると いまだ不明の点が多い, しかし現在までのとてろでは動物の種類により一定はしないが心や骨格筋でのアド レナリンによるホスホリラーゼの活性化と Glycogenolysis は $\beta$ 遮断剤で阻止され， $\alpha$ 遮断剤では阻止され ないとされている(6)47)48).

著者の実験においても無処置群にプロプラノロールを投与し，その後にアドレナリンを加えてもホスホリ ラーゼ活性の上昇は認められなかつたが，フェントラミン投与ではアドレナリンによるホスホリラーゼ活性 の上昇は阻止できなかつた。サイロキシン投与群においてはプロプラノロール投与後にアドレナリンを加光 ても心筋ホスホリラーゼ活性の上昇が認められないのみならず，フェントラミン投与後にアドレナリンを加 えても活性の上昇が誌められず，甲状腺機能充進状態ラットにおいてはアドレナリンの効果が認められなか つた。 また無処置およびサイロキシン投与雨群においてプロプラノロールを投与すると心搏数は減少し，か つアドレナリン投与による心搏数の増加が抑制された。一方フェントラミン投与においては心搏数はやや増 加した值を示しかつアドレナリン投与による心搏数の増加を抑制するととをは出来なかつた．すなわち無処 置ラットにおけると同様のプロプラノロール投与により, サイロキシンによる心符ホスホリラーゼ活性の上 昇が抑制されないととはサイロキシンが $\beta$-receptor の働きを光進せしめているという可能性をも否定して いる.また心搏数が貲処置ラットおよびサイロキシン投与ラットにおいて減少するてとは心搏数の変化が sympathetic tone の最も鋭敏な指標であるためであろう.

以上のベたでとく内因性およで外因性カラコールアミンとも心におけるサイロキシンの作用を増強せしぬ ている証拠はえられなからたが前述した種々の報告, 臨床的観祭および甲状腺機能立進症㭧者にカテコール アミンを投与したとき正常人と異る反応を示すという私共の成績(9)などから考觉ると甲状腺ホルモンとカテ コールアミンとの関係はなお今後一㬝の研究を要する問題であると考学る.

\section{結 語}

甲状腺機能元進症におけるカテコールアミンの役割を知るために, サイロキシン投与により甲状腺機能立 進状態となつたラットを用い，心笳内䢶スリラーゼ活性および心搏数の変化を示標として笑験を行ない次 のごとき結論をえた。 
1） L-サイロキシンソーダ $100 \mu \mathrm{g} / 100 \mathrm{gm}$ を 6 日間腹腔内に投与するととにより酸素消費量，心搏数の 増加，体重の減少を来たし，ラットが甲状腺機能卉進状態となつたととを確かめた。

2）サイロキシン投与によりラットの心，副腎，脾，腎の組織内カテコールアミン量はやや減少した值を 示したが，肝における組織内カテコールアミン含有量には変化がなかつた。しかしその減少の度合は有意の 差ではなかつた。一方レセルピン投与により, 副腎, 脾, 简, 肺内のカテコールアミン含有量は著明に減少 した.

3) サイロキシン投与群では心筋ホスホリラーゼ活性の上昇および心搏数の増加を認めた。サイロキシン ナレセルピン投与群では心筋ホスホリラーゼ活性はサイロキシン単独投与を行なつた場合より高い值を示し たが心搏数の増加は抑制された。レセルピン投与群では心笳ホスホリラーゼ活性はやや上昇した值を示した が心搏数は減少した值を示した。

かくのごとく内因性カテコールアミンの濃度と心筋ホスホリラーゼ活性との間にはなんらの関係も認もら れなかつた。

4）アドレナリンに比しノルアドレナリン投与では心筋ホスホリラーゼ活性の上昇の度合が小さかつた。 5 ）無処置群，サイロキシン投与群，サイロキシン十レセルピン投与群，レセルピン投与群备々にアドレナ リンを投与すると無処置群，およびレセルピン投与群では心筋ホスホリラーゼ活性の上昇を認妨たがサイロ キシン投与群，サイロキシン十レセルピン投与群ではアドレナリン投与による心筋ホスホラリーゼ活性の上 昇は認められなかつた．すなわちサイロキシンとカテコールアミンの協働作用は認められないのみならずア ドレナリンの作用がサイロキシン投与群では認められなかつた。 またアドレナリン投与後の心搏数の増加は サイロキシン十レセルピン投与群，レセルピン投与群において著しかつた。

6) プロプラノロール投与を行ならと無処䁂群，サイロキシン投与群とも心筋ホスホリラーゼ活性には変 化を認めなかつたが，心搏数の減少を認めた。フェントラミン投与では心筋ホスホリラーゼ活性，心搏数と も変化を認めなかつた。 さらにプロプラノロール投与後にアドレナリンの投与を行うと無処置群ではアドレ ナリンによる心筋ホスホリラーゼ活性の上昇が抑制されたがフェントラミンではその効果が認められなかつ た.すなわた無処置群にわけると同様にプロプラノロール投与により，サイロキシンによる心筋ホスホリラ 一ゼ活性の上昇が抑制されないととはサイロキシンが $\beta$-receptor の働きを充進せしめているという可能性 を否定している。

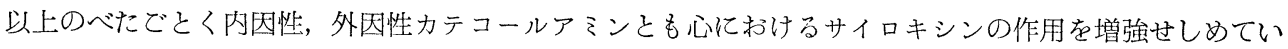
る証拠はえられなかつたが甲状腺ホルモンとカテコールアミンとの関係は今後なお一層の検討を要する問題 であると考える。

本論文の要旨は第41回日本内分泌学会総会において発表した。

稿を終わるにあたり，䅰篤なる御指導ならびに御校閲を晹わつた恩師木村武教授に深謝する。

\section{文献}

1）木村 武, 井上一彦, 安達敏昭, 及川量平, 勝又 厚：日本内分泌学会雑誌, 44巻：1号揭载予定

2）井上一彦, 安達敏昭, 及川量平：日本内分泌学会雑誌投稿中. 35 井上一彦, 岩手医学雑誌：19 巻184頁 (昭和42年). 105, (1956).

4) GORI, G.T. and B. ILLINGWORTH : Biochim. biophys. Acta, 21 :

5) 藤井暢三 : 生化学実験法定量篇, 13版（昭和39年), 163, 南山堂.

BREWSTER, W.R., J.P. ISAACS, P.E. OSGOOD and T.L. KING : Circulation, 13:12, (1956)

7）飯野史郎：日本内分泌学会雑誌，34巻，978頁. and L.H. KYLE : New Eng. J. Med., 257 : 435, (1957).

8) GANARY, J.J., M. SHAFF, B.J. BUFFY LANDS : Am. Heart. J., $73: 282$, (1967). Physiol, $22: 207$, (1967).
9) HOWITT, G. and D.J. ROW-
11) SCHNECKLOTH, R.E., G.S. KURLAND and A.S. FREED- 
BERG : Metabolism, $2: 546$, (1953).

12) SVEDMYR, N. : Acta. physiol. scand, $66: 257$,

(1966). 13) WURTMAN, R.J., I.J. KOFIN and J. AXELROD : Endocrinology, 73: 63,

14) BUGGINO, R.A., J.F. SPANN., P.E. POOL., E.H. SONNENBLICK and E.

BRAUNWALD : J. clin. Invest, $46: 1669$, (1967).

BRODY : J. Pharmacol. Exptl. Therap, $140: 295$, (1963).
15) HORNBROOK, K.R. and T.M.

16) MAYER, S.E., M. de V.

COTTEN and N.G. MORAN : J. Pharmacol. Exptl, Therap, 139 : 275, (1963).

17) WOL-

LENBERGER, A., E.G. KRAUSE and L. MACHO : Nature, 201 : 789, (1964).

18) HESS,

M.E. and J. SHANFELD : J. Pharmacol. Exptl. Therap., $148: 290$, (1965).

19) HAUGAARD, N., M. E. HESS., J. SHANFELD., G. INESI and W. R. KUKOVETZ : J.Pharmacol. Exptl. Therap., $131: 137$, (1961).

20) HESS, M.E., J. SHANFELD and N. HAUGAARD : J. Pharmacol. Exptl. Therap., $131: 143$, (1961). 21) MOON, R.G. and C.W. TURNER : Proc' Soc. exp. Biol., $100: 679$, (1959).

22) BIERWAGER, M.E. ann D.L. SMITH : Proc. Soc. exp. Biol., 100 : 108, (1959). 23) MAYER, S.W., F.H. KELLY and M,E. MORTON : J. Pharmacol. Exptl. Therap., $117: 197$, (1956). 24) LEDUG, J., R. DUBREUIL and A. D'IORIO: Canad. J. Biochem. Physiol., 33 : 283, (1955). ROBERTS : Am. J. Physiol., 201 : 1049, (1961).

25) GOODKIND, M.J., D.H. FRAM and M. 26) BURSTEIN, J., N.T. KAERKI and A. TELKKAE : Ann. Med. Exptl. Biol. Fenn., $42: 128$, (1964). $\quad$ 27) HOPSU, V.K.: Ann. Med. Exptl. Biol. Fenn., $38: 432$, (1960).

28) PEKKARINEN, A., M. KOIRUSALO and K. PYÖRALA : Acta. Endocr., $6: 233$, (1951). 29) FR ÄNKO, O. : Acta. Anatomica, 16 : Suppl 17, (1952) 30) D'IORIO, A.and G.W.E. PLAUT : Arch. Biochem. Biophys., 41 : 153, (1952). $\quad 31)$ HESS, M.E. and J. SHANFELD : J. Pharmacol. Exptl. Therap., 148 : 290, (1965) 32) HORNBROOK, K.R. and T.M. BRODY : J. Pharmacol. Exptl. 'Therap., 140 : 295, (1963).

33) HORNBROOK, K.R. : Biochem. Pharmacol., 14 : 425, (1965).

34) MAYER, S.E. and N.G. MORAN : J. Pharmacol. Exptl. Therap., 129 : 271, (1960).

35) BELFORD, J. and M. R. FEINLEIB : Biochem. Pharmacol., $6:$ 189, (1961).

36) BLOOM, W.L. and J.A. RUSSEL : Am. J. Physiol., 183 : 356, (1955).

37) FLEMING, W.W. and A.O. KENNY : Brit. J. Pharmacol., $22: 267$, (1964). 38) HAUGAARD, N. : Nature, $197:$ 1072, (1963).

39) ØYE, I. : Acta. Physiol. Scand., 65 : 251, (1965). 40) DRUMMOND, G.I., J.R.E. VARADARES and L. DUNCAN : Proc. Soc.exp. Biol., 117 : 307, (1964). 41) RAAB, W. : J. Pharmacol. Exptl. Therap., 82 : 330, (1944).

42) AHLQUIST, R.P. : Am. J. Physiol., 153 : 586, (1948). 43) POWELL, C.E. and I.H. SLATER : J. Pharmacol. Exptl. Therap., 122 : 480, (1958). 44) BLACK, J.W. and J.S. STEPHANSON : Lancet, II : 311, (1962).

45) BLACK, J.W. : Lancet, I : 1080, (1964). Int. Pharmacodyn, $126: 332$, (1960).

Pharmacol. Exptl. Therap., 134 : 18, (1961). Exptl. Therap., $136: 209$, (1962).
46) CLAASSEN, V. and E.L.NOAGH : Arch. 47) MAYER, S.E., N.C. MORAN and J. FAIN : J. 48) MGGUTGHEON, R.S. : J. Pharmacol. 49）末発表データ. 